\title{
Reconstruction of Policy for the Termination of Investigation by the Commission for Eradication of Corruption Based on the Pancasila's Value of Justice
}

\author{
Gunarto $^{1 *}$, Tabana Bangun ${ }^{2}$, Eko Soponyono ${ }^{1}$ \\ ${ }^{1}$ Faculty of Law Sultan Agung Islamic University Semarang, Indonesia \\ ${ }^{2}$ Doctorate Student of Faculty of Law Sultan Agung Islamic University Semarang, Indonesia
}

\begin{abstract}
DOI: $\underline{10.36348 / \mathrm{s} j \mathrm{shs} .2020 . \mathrm{v} 05 \mathrm{i} 11.002}$
| Received: 13.10.2020 | Accepted: 28.10.2020 | Published: 03.11.2020
\end{abstract}

*Corresponding author: Gunarto

\section{Abstract}

The implementation of the termination of investigations by the Indonesia's Commission of the Eradication of Corruption (KPK) in Indonesia has not been able to provide justice due to the unclear regulatory factors in Law Number 19 of 2019 concerning the Amendment of the KPK Law. Based on this, the problem raised by the writer in this study is what are the obstacles that arise in in the process of investigation by the KPK in realizing the principles of fast, cheap, and simple Investigation and how to reconstruct the termination of an investigation by the KPK from the perspective of Law Number 19 of 2019. The research method used in this research is normative juridical using secondary legal materials and a qualitative analysis. The results showed that in its development, the investigation policy for suspects who died had changed since the second amendment to Law no. 30 of 2002. Several considerations behind the change in the policy of stopping KPK investigations are to provide protection for the rights of suspects. To deal with this, a reconstruction of the policy to stop investigations in the criminal justice system for corruption cases under the authority of the Corruption Eradication Commission requires reconstruction in Article 40 paragraph (1) of Law no. 30 of 2002, by adding to the provision that the KPK can stop investigating and prosecuting corruption cases where the investigation and prosecution are not completed within a maximum period of 2 (two) years or if there is not enough evidence, not a criminal act and for the sake of the law.

Keywords: Termination of Investigation, KPK, Pancasila Justice.

Copyright (C) 2020 The Author(s): This is an open-access article distributed under the terms of the Creative Commons Attribution 4.0 International License (CC BY-NC 4.0) which permits unrestricted use, distribution, and reproduction in any medium for non-commercial use provided the original author and source are credited.

\section{INTRODUCTION}

In Indonesia, The termination of investigations of the criminal acts of corruption in accordance with Article 40 paragraph (1) of Law No. 30 of 2002 (amendment II), states that the reason for the determined termination is because the investigation was not completed within 2 years. Meanwhile, the reason for stopping the investigation is because the suspect has passed away is not used as an excuse. This is very different from Law no. 30 of 2019 (amendment I), where Indonesia's Commission of the Eradication of Corruption (KPK) investigators are unable to stop the investigation at all, including cases where the investigation was not completed in 2 years or when the suspect died. So that before the second amendment to Law No. 30 of 2002, in the case where the investigation of a corruption case where the investigation was not completed for 2 years, then KPK investigators did not have the authority to stop the investigation. The absence of this authority has resulted in the investigation of a criminal act of corruption even though the suspect has died, there is no continuation of the case and there is no clear certainty of the time until when the suspect's status is attached to the suspect who has passed away. The failure to terminate the investigation has resulted in a lack of sense of legal justice, because the suspect's status is still carried by the person concerned without a definite time limit, even though the suspect has passed away.

The reasons for stopping the investigation in Law no. 30 of 2002 (after the 2nd Amendment), in relation to the Criminal Procedure Code, have different provisions in terminating an investigation of a criminal case. In the Criminal Procedure Code, one of the reasons for terminating an investigation is because the suspect has died (not because the investigation was not completed within 2 years). Meanwhile, the provisions 
for termination of investigation as Law No.30 of 2002 (2nd amendment) are used as the reason is the time limit for investigations that are not completed within a period of 2 years. A corruption case can only be stopped if the investigation or prosecution process cannot be completed within 2 years. In other words, the KPK can only stop investigations into corruption cases, which are not completed within 2 years. This provision certainly does not imply that the KPK can terminate investigations into corruption cases where the suspect has died.

Furthermore, when viewed from the provisions of Article 40 paragraph (1) of Law No. 30 of 2002, which states that investigations and prosecutions are not completed within a period of 2 years, it gives the understanding that if a corruption case where the suspect dies during the investigation stage, if it is to be stopped then must take into account (past) the investigation period not completed within a period of up to 2 (two) years. This of course creates a conflict with the principle of law, which states that a trial is fast and simple. Because if a suspect dies, even though the KPK investigator will not allow the suspect (who has passed away) to face the KPK public prosecutor, the KPK cannot immediately terminate the investigation. This is because in order to comply with the provisions on termination of investigation which states that "a corruption case where the investigation and prosecution are not completed within a maximum period of 2 (two) years', has to wait for a period of up to 2 years, while on the other hand, the need to wait for 2 years may cost time to not only the investigator but also the suspect [1].

From the description above, in the second amendment to Law no. 30 of 2002, there are law enforcement problems that cause the investigation of criminal acts of corruption to be inconsistent with the principles of a trial that is fast, cheap, and simple. In order to avoid the existence of corruption cases that contradict the principles of fast, cheap, and simple, then it is necessary to carry out legal restructuring (reconstruction) in relation to stopping the investigation of corruption crimes. This legal arrangement will eliminate the slow legal action (investigation) of the corruption case in order to realize the value of justice, especially for the suspect or other related parties [2].

Another thing that can be seen from the provisions on stopping the investigation of corruption cases is stipulated in Law no. 30 of 2002 (2nd amendment), and the termination of investigation as stipulated in the Criminal Procedure Code, it can be seen that there are differences. The Criminal Procedure Code states clearly that the termination of investigation of a suspect who has died can be carried out without waiting for up to 2 years. This is stated in article 109 paragraph 2 of the Criminal Procedure Code, on the grounds that for the sake of law article 77 KUHP. This difference can be seen as a situation that illustrates the lack of equality and equality before the law in dealing with corruption suspects who have died. If it is related to the Criminal Code (KUHP), especially in the general explanation of number 3 letter (a) of the Criminal Code which says: "Equal treatment of each person before the law without making differences in treatment".

The meaning of the above explanation directs that law enforcement which is determined through the provisions and procedures of law enforcement which are practiced in law enforcement (investigation) of corruption crimes must have equality (nondiscrimination), as a form of manifesting our own sense of justice [3]. The legal procedure applied by law enforcement officials against a suspect must not be different in the same case. If there are still legal procedures with different arrangements, even though the cases handled are the same case (corruption), then it is appropriate to carry out legal reform [4].

Judging from the explanation above, the law enforcement process (investigation) must pay attention to any non-discriminatory legal action. Differences in action (discriminatory) against the passing of the same law in law enforcement, at least have given the meaning that law enforcement carried out by investigators is not in line with the principle of equality before the law, thereby reducing the value of legal justice itself. If there is a discriminatory law enforcement provision, not done quick, cheap, and simple in handling corruption, then that means that it violates the principle of justice. Based on the various problems above, the authors are interested in discussing them in a study with the following issues:

1. What obstacles arise in the KPK's termination of the investigation in order to realize the principles of fast, cheap, and simple Investigation in Indonesia?

2. How is the reconstruction of the article on the termination of the investigation by the KPK in Law Number 19 of 2019?

\section{METHOD OF RESEARCH}

The paradigm that is used in the research this is the paradigm of constructivism which is the antithesis of the understanding that lay observation and objectivity in finding a reality or science knowledge [5]. Paradigm also looked at the science of social as an analysis of systematic against Socially Meaningful Action through observation directly and in detail to the problem analyzed.

The research type used in writing this paper is a qualitative research. Writing aims to provide a description of a society or a certain group of people or a description of a symptom or between two or more symptoms.

Approach method used in this research is Empirical-Juridical [6], which is based on the norms of 
law and the theory of the existing legal enforceability of a law viewpoint as interpretation.

As for the source of research [7] used in this study are:

1. Primary Data, is data obtained from information and information from respondents directly obtained through interviews and literature studies.

2. Secondary Data, is an indirect source that is able to provide additional and reinforcement of research data. Sources of secondary data in the form of: Primary Legal Material and Secondary Legal Materials and Tertiary Legal Material.

In this study, the author use data collection techniques, namely literature study, interviews and documentation where the researcher is a key instrument that is the researcher himself who plans, collects, and interprets the data. Qualitative data analysis is the process of searching for, and systematically compiling data obtained from interviews, field notes and documentation by organizing data into categories, describing it into units, synthesizing, compiling into patterns, selecting important names and what will be studied and make conclusions.

\section{RESEARCH RESULT AND DISCUSSION Obstacles That Rise In the KPK's Termination of the Investigation In Order To Realize the Principles of Fast, Cheap, and Simple Investigation in Indonesia}

The weakness of the policy to stop investigating criminal acts of corruption is basically closely related to the authority of the KPK in terminating investigations of the criminal acts of corruption. This discussion will also be linked to laws and regulations, which regulate the authority of KPK investigators to investigate criminal acts of corruption, which since the establishment of the KPK institution as stipulated in Law No. 30 of 002, the KPK is not authorized to stop investigations of corruption crimes.

In the process of law enforcement for criminal acts of corruption, especially in the period before the KPK was formed (before Law No. 30 of 2002), investigations of corruption were carried out by police investigators and prosecutors. Police investigators and prosecutors' investigators carry out their duties to investigate corruption based on the criminal procedure law, namely Law no. 8 of 1981 concerning The Criminal Procedure Code (KUHAP). The Criminal Procedure Code regulates the authority of police investigators and the prosecutor's office to terminate investigations of suspects who have died. With this, police investigators and the prosecutor's office can stop investigating corruption suspects who have died immediately without waiting for a long time. Then according to the enactment of Law no. 30 of 2002 which established the KPK as a new institution that has the authority to enforce the law in corruption cases. With the formation of the Corruption Eradication
Commission which has the authority to investigate criminal acts of corruption, the investigating apparatus of corruption has increased to become 3 (three) institutions authorized to investigate corruption crimes, namely investigators at the KPK and investigators at the Police and investigators at the Attorney General's Office.

According to Law no. 30 of 2002, it was determined that the KPK in carrying out its duties to investigate criminal acts of corruption, investigation procedures are based on this Law and other laws as long as it is not specified in Law No. 30 of 2002. Other laws referred to here are the Criminal Procedure Code. Thus, the first to be guided by KPK investigators in investigating corruption crimes are the provisions in Law no. 30 of 2002. If the procedural law provisions in Law no. 30 of 2002, the KPK followed the investigation procedures stipulated in the Criminal Procedure Code, as procedural law.In law no. 30 of 2002 (before the 2nd amendment) states that the KPK does not have the authority to stop investigations. This is stated clearly and firmly in Article 40. This provision causes the KPK not to have the authority to stop investigations. Therefore, the KPK is not authorized to stop investigations on any basis, even though the suspect dies. This is different from the provisions in the Criminal Procedure Code which authorize police investigators and prosecutors to stop investigations. Although in law enforcement the KPK underlies the Criminal Procedure Code because in article 39 paragraph (1) of Law No. 30 of 2002 it is stated that the procedures for investigations, investigations and prosecution of criminal acts of corruption are carried out based on the applicable criminal procedural law and based on Law Number 31 of 1999 concerning Eradication of Corruption Crimes as amended by Law Number 20 of 2001 concerning Amendments to Law Number 31 of 1999 concerning Eradication of Corruption Crimes unless otherwise stipulated in this Law.

This provision means that the KPK does not have the authority to stop investigations. Thus, even though in the Criminal Procedure Code authorized investigators to stop investigations, because the KPK must first follow Law No. 30 of 2002, the KPK does not have the authority to stop investigations. With this provision, the Corruption Eradication Commission cannot stop investigating acts of corruption even though there are corruption cases that actually have the same reasons stated in the Criminal Procedure Code.

In the policy of criminal law enforcement procedures regulated in the Criminal Procedure Code, including regulating the authority of investigators, terminating investigations. In terminating an investigation of a criminal act regulated in accordance with the Criminal Procedure Code, it is required that the 
reasons or criteria serve as the basis for terminating the investigation itself.

Referring to the provisions above, since the establishment of the KPK in 2002 in law enforcement carried out by KPK investigators, it has never stopped investigations into corruption cases, even though if they are linked to the Criminal Procedure Code it has actually met the requirements for terminating investigations. During the enactment of Law number 30 of 2002, there have been cases of corruption in which the suspect has died and there has been no stopping the investigation. In the absence of a halt to investigations, cases of corruption are unclear, because they cannot be processed until prosecution and trial and cases simply stop. This is different from police and prosecutor investigators who have the authority to stop investigations into criminal acts of corruption, in accordance with the requirements for terminating investigations as regulated by the Criminal Procedure Code. One of the reasons or conditions for an investigation to be terminated by police and prosecutorial investigators is because the suspect has died. This reason is the basis for police investigators and prosecutors' investigators to stop investigating a corruption case where the suspect has died.

From the description above, it can be said that in the law enforcement against criminal acts of corruption, there are differences in the authority of investigators in terms of stopping investigations of corruption cases, even though those handled by corruption cases where the suspect died. This difference in authority can of course be seen as a difference in providing protection for the rights of the suspect even though the cases are the same. In this case, the difference between the protection of suspects in the same case is related, but, if handled by the KPK the investigation cannot be stopped, while a corruption case if handled by Police investigators and Attorney General's investigators can be terminated, therefore a corruption case handled by the KPK can cause it to drag The investigation of the case longer and there is no certainty about the time and clarity of the status of the suspect and it is most likely that if someone has been declared a suspect and then dies, the status as a suspect is likely to remain attached to a person for a long time and there is no legal certainty.

Meanwhile, if a corruption case is carried out, the investigation by the police and the prosecutor's office where the suspect dies, the investigation can be stopped. This provides more legal certainty and is in line with the principles of a fast, cheap, and simple trial and the status of suspects can be quickly determined.

The termination of the investigation will automatically restore the rights of the suspect, as a person who has not had any mistakes, because he has not yet gone through a court hearing that has determined his guilt. The stopping of investigations into criminal acts of corruption is actually related to efforts to provide legal certainty in order to achieve justice. This is based on the explanation that the policy of terminating investigations is one of the legal actions that are included in the principles of criminal procedure law related to the protection of the rights of suspects even if they die even though Protecting the rights of suspects is part of providing a sense of justice to the suspect.

Yahya Harahap [8] stated that the rights of suspects which also need to be protected in accordance with the principles of criminal procedure law are in the case of examination of suspects who must be immediately examined, as referred to in Article 50 of the Criminal Procedure Code. It says the explanation of the word immediately is "as soon as possible" or "right now". Therefore, in the absence of the authority to stop investigations, it can be said that the law enforcement carried out by the KPK since 2002 in a corruption case where the suspect died is not in line with the principles of cheap, fast, and simple. In this case, because the KPK does not have the authority to stop investigations in accordance with the principles of cheap, fast, and simple, the enforcement of this law does not reflect the protection of the rights of the suspect even if the suspect dies.

\section{Reconstruction of the Article on the Termination of the Investigation by the KPK in Law Number 19 Of 2019}

Changes to law enforcement policies in terms of terminating investigations are basically built on the concept of thinking that is in line with the principle of respect for the rights of suspects. The new policy also stipulates provisions to stop investigations of corruption cases, including those in which the suspect has died. This means that with the establishment of a new policy, there is an assessment process that aims to assess a number of alternatives in determining law enforcement activities, including in determining policies to stop corruption investigations.

However, the reason for the termination of the investigation in the new law is because "the investigation is not completed within a maximum period of 2 (two) years, as stated in the amendment to Article 40 paragraph (1), namely the Corruption Eradication Commission can stop investigations and prosecutions of cases. Corruption Crime whose investigation and prosecution is not completed within a maximum period of 2 (two) years."

The understanding of the incomplete 2 year period is related to the requirements for law enforcement on corruption, which include requiring suspects to be confronted by investigators to the KPK Prosecutors, so suspects who die in the investigation stage mean that it is not possible to be brought before 
the KPK Prosecutors. Therefore, if a suspect dies, it is included in the incomplete category within 2 (two) years.

The concept of the new legal policy referred to is a policy in the field of criminal procedural law, which is directed among others to respect the rights of suspects, including suspects who have died during the investigation stage. Among them, respect for the rights of the suspect remains based on the principle of criminal procedural law. One of the principles of criminal procedure law related to respect for the rights of suspects is the importance of conducting an immediate examination of the suspect and the defendant needs to be immediately submitted to the court to examine the alleged case. This is in line with the principles of the Criminal Procedure Code, namely a fast, cheap, and simple trial. This principle is of course also part of the principles in investigations that should be part of the policies governing KPK investigations, which are contained in the procedural law which becomes the basis for KPK investigators to take legal action.

With the existence of a judicial principle that is fast, cheap, and simple, in the manifestation of terminating an investigation, it is one of the efforts to realize the value of justice, especially for suspects who have died during the investigation stage. This is based on the premise in law enforcement that a suspect who has died is no longer possible to be held accountable for his actions, the need for a suspect's status to be determined quickly (does not drag on in the investigation stage) and immediately obtain legal certainty for the suspect's position in a criminal act.

The formal criminal law policy above, which concerns the authority to terminate an investigation by the KPK, as the right of the suspect, should be carried out immediately, based on the conditions that have been fulfilled or the legal reasons for the termination to complete. One of the provisions that become the reason for terminating the investigation is that the suspect has died. Based on the explanation of the principle of fast, cheap, and simple, the realization of the suspect's rights must be enforced at the first opportunity without waiting for a longer time. This must be applied by KPK investigators to "terminate the investigation" against a suspect who has died, in applying the "immediately" principle. The new policy to stop investigations is as stipulated in Law no. 19 of 2019, on the background of a case where the suspect died, but the KPK investigators did not stop the investigation.

What is meant by the revision of the KPK Law is the amendment to Law no. 30 of 2002 with revisions based on law. 19 of 2019, which gives the KPK authority to issue SP3. One of the reasons for the change is to protect the rights of suspects. Judging from the description above, the statutory policy regulating the cessation of investigations is a way out of the desire to resolve a number of problems because there are corruption suspects who do not get their rights to undergo legal proceedings quickly, cheaply, and simply, as part of justice and legal certainty.

Investigations conducted by the KPK prior to Law no. 19 of 2019, in the investigation there is a suspect who died, it is felt that it does not provide legal certainty to the suspect. The lack of authority to stop investigating a suspect who has died is an obstacle to protecting the rights of the suspect, so there is no certainty about the time limit that determines the time limit for the status of the suspect who dies. Moreover, the suspect's status has been carried for a long time. So it is clear that before the changes were made, the rights of suspects were not protected.

From the explanation above, it can be seen that the need to stop investigations is needed in law enforcement, although it is stated that the mechanism for terminating investigations can be carried out by placing this authority on KPK Advisors to avoid any potential or opportunity for certain interests that are contrary to law enforcement objectives. This, of course, is based on the view that stopping investigations is thought to have been used as a way to only act to benefit certain parties. But from this regulation, an understanding can be drawn that stopping investigations by the KPK is a necessity in eradicating criminal acts of corruption.

In connection with the previous discussion, the opinion that states the need to stop the investigation above has gone through a study which is part of the policy in Law No. 19 of 2019 (regarding the 2nd amendment to Law No. 30 of 2002) concerning the need to stop investigations of suspects who have died and in its implementation it has been stated in article 40 of the KPK Law. From the existence of the policy of terminating the investigation as part of the Academic Paper above which is the result of a scientific review, the termination of investigation as part of law enforcement is at least part of efforts to improve the effectiveness of the crime prevention system from controlling the use of the power of the investigating apparatus itself and in order to protect the suspect's rights.

This is in line with the principles in criminal procedural law, especially in law enforcement, which by Monang Siahaan [9], states that; "To support the presumption of innocence and accusator of the principles in law enforcement, the Criminal Procedure Code has provided a shield for suspects and defendants in the form of a set of human rights that must be respected and protected by law enforcement officials."

Even though KPK investigators have the authority to stop investigations, there are still 
differences in the policy to stop investigations. The difference in policy is that the KPK is given a time limit to stop corruption investigations after investigations and prosecutions are not completed within 2 years. Meanwhile, the police and prosecutors are not given a time limit [10]. Then in terminating the investigation, the police and the prosecutor's office can immediately terminate the investigation, if the suspect has passed away. KPK investigators in stopping investigations are not mandatory but "can" stop investigations in accordance with Article 40 of the Law. No. 30 of 2002.

Based on the foregoing, the provisions in Law Number 19 of 2019 concerning the KPK regarding the termination of investigation and prosecution are listed in Article 40 paragraph (1), which reads: (1) The Corruption Eradication Commission can stop investigations and prosecutions of cases of Corruption Crime those whose investigations and prosecutions have not been completed within a maximum period of 2 (two) years need to be reconstructed because the formulation of the article uses the word "can stop investigation and prosecution". The word "can" gives a dual or alternative meaning, so it will heavily depends on the decision/view of the investigator and the public prosecutor. As a result of the word, there is no legal certainty and is strongly influenced by the subjectivity of the Investigator, because the Investigator can stop the investigation or the Investigator does not stop the investigation.

Article 40 paragraph (1) of Law No.19 of 2019 uses the phrase investigation and prosecution. The phrase raises a cumulative meaning but in practice, it cannot be done simultaneously, namely: stopping the investigation "and" prosecution, because one of the implementations can be done, namely in the stage of investigation or prosecution.

The construction of Article 40 paragraph (1) of Law No.19 of 2019 provides a cumulative meaning that creates uncertainty of meaning, namely terminating investigations at the same time with terminating prosecution or terminating investigations that are separate from termination of prosecution. Construction of Article 40 paragraph (1) of Law No. 19 of 2019 with the word "and", if linked to a warrant, it can be interpreted as an order to terminate investigations and prosecutions are simultaneously issued, a separate order for termination of investigation with an order for termination of prosecution, The definition of "not finished", as the reason for terminating the investigation and prosecution.

From the reasons for terminating the investigation and prosecution mentioned above, it can give a meaning that the results of the investigation have not fulfilled the completeness submitted to the prosecution stage. The results of the prosecution have not met the requirements to be submitted to the trial court examination stage, the Corruption Eradication Commission immediately stops the investigation or prosecution in accordance with the applicable legal provisions.

Therefore, based on article 40 paragraph (1) of Law 19 of 2019, the Corruption Eradication Commission can stop investigations and prosecutions of cases of Corruption Crime whose investigations and prosecutions have not been completed within a maximum period of 2 (two) years. The provisions regarding the 2 (two) year period need to be reconstructed because there is no definite explanation regarding the terms of that period.

\section{CONCLUSION}

1. Investigation policies on suspects who have died have changed since the second amendment to Law no. 30 of 2002. Several considerations behind the change in the policy of stopping KPK investigations are to provide protection for the rights of suspects. This can be seen in their considerations, including that the police, prosecutors, and KPK that handle corruption cases need synergy in eradicating criminal acts of corruption based on the principle of equal authority and protection of human rights. Another consideration is that the implementation of the KPK's duties needs to be improved without neglecting respect for human rights according to legislation. Judging from these considerations, the effort to realize human rights protection including protection of the rights of suspects is an aspect that is wanted to be realized in the investigation of the corruption crime. This is in line with the principles contained in the Criminal Procedure Code which outlines the principles of fast, cheap, and simple trial. This principle puts forward the investigation process to be carried out promptly and not long-winded so that the suspect can immediately get the verdict of the case that he or she is facing. In accordance with the provisions in the second amendment, it is stated that the KPK has the authority to stop investigations of criminal acts of corruption which the investigation and prosecution have not completed within a period of 2 (two) years.

2. The reconstruction of the policy to stop investigations of a corruption cases where the suspect has died based on the value of Pancasila justice, includes: First, the policy of stopping investigations in the criminal justice system of corruption cases under the authority of the KPK is reconstructed in article 40 paragraph (1) of Law no. 30 of 2002, by replacing "the KPK stops investigating and prosecuting cases of criminal acts of corruption whose investigations and prosecutions are not completed within a maximum period of 2 (two) years", to "KPK can stop investigating or prosecuting cases of criminal acts 
of corruption that are investigating or prosecuting not completed within a maximum period of 2 (two) years, or there is insufficient evidence, not a criminal act and for the sake of law". Second, there must be values of Pancasila justice in the termination of the investigation of corruption case by manifesting it in the policy of stopping investigations by the KPK on corruption cases where the suspect has died so that it can be in line with the principles of a fast, cheap and simple trial.

\section{REFERENCES}

1. Modesto, J., \& Pilati, R. (2020). "Why are the Corrupt, Corrupt?": The Multilevel Analytical Model of Corruption. The Spanish Journal of Psychology. 23. 10.1017/sjp.2020.5.

2. Thalib, H., Ramadhan, A., \& Djanggih, H. (2017). The Corruption Investigation In The Regional Police of Riau Islands, Indonesia. Rechtsidee, 4. 10.21070/jihr.v4i1.988.

3. Sosiawan, U. (2019). Peran Komisi Pemberantasan Korupsi (KPK) Dalam Pencegahan dan Pemberantasan Korupsi. Jurnal Penelitian
Hukum De Jure. 19:517.

10.30641/dejure.2019.V19.517-538.

4. Wahyuningrum, K., Disemadi, H., \& Jaya, N. (2020). Independensi Komisi Pemberantasan Korupsi: Benarkah Ada?. Refleksi Hukum: Jurnal Ilmu Hukum. 4:239-258. 10.24246/jrh.2020.v4.i2.p239-258.

5. Faisal. (2010). Menerobos Positivisme Hukum, Rangkang Education, Yogyakarta.

6. Johnny, I. (2005). Teori dan Metodologi Penelitian Hukum Normatif, Bayumedia, Surabaya.

7. Moleong, L. (2002). Metode Penelitian Kualitatif, PT Remaja Rosdakarya, Bandung.

8. Yahya, M. H. (2014). Pembahasan Permasalahan dan Penerapan KUHAP Penyidikan dan Penuntutan, Sinar Grafika, Jakarta

9. Monang, S. (2016). Pembaharuan Hukum Pidana Indonesia, PT. Grasindo, Jakarta, 183.

10. Wahyu, W., Sapto, B., Toebagus, G., \& Windi, P. (2018). The Role of Law Politics on Creating Good Governance and Clean Governance for a Free-Corruption Indonesia in 2030. The Social Sciences, 13: 1307-1311. 